\title{
FACTORS AFFECTING METAL AND RADIONUCLIDE POLLUTION IN THE BALTIC SEA
}

\author{
MARTIN LODENIUS* \\ Department of Environmental Sciences, University of Helsinki, Finland \\ *Corresponding author: martin.lodenius@helsinki.fi
}

\section{ABSTRACT}

External pollution load in the Baltic Sea originates from urban, agricultural and industrial sources. Emissions of heavy metals have decreased substantially in the catchment area but the temporal trends are not always significant and differ with sample, area and pollutant. The most significant source of anthropogenic radioactivity in the Baltic Sea is fallout from the Chernobyl accident in 1986. Many factors affect the future development of pollutant concentrations including anthropogenic emissions, political decisions and changes in salinity, temperature and water currents, in eutrophication and oxygen status, in fisheries and in atmospheric deposition of pollutants. Large scale changes like eutrophication and climate change affect ecosystems in many ways, directly and indirectly, causing biological and abiotic effects. These factors are interrelated and difficult to predict. Measures aiming to enhance the ecological status of the Baltic Sea will certainly give positive results but this will take at least several decades.

Keywords: Baltic Sea, cadmium, lead, mercury, radionuclides, pollution, pressure

\section{Introduction}

The Baltic Sea is one of the most polluted seas in the world and its ecological status is affected by it being relatively shallow, slow water renewal and a salinity gradient increasing from zero to $2.5 \%$. Salinity and temperature stratification limit water exchange and oxygen depletion is common at the bottom in deep areas. In addition to the thermocline there is a halocline at a depth of about $40-70 \mathrm{~m}$. The salinity increases from 2-4 PSU in the Bothnian Bay to 6-8 PSU in the Baltic proper, while the water below the permanent halocline is up to 13-20 PSU (Elmgren 2001). The area of the Baltic Sea is approximately $350,000 \mathrm{~km}^{2}$ with a drainage area covering 1.74 million $\mathrm{km}^{2}$ in fourteen countries. The catchment area of the Baltic Sea consists of forests (54\%), agricultural land (26\%), wetlands or drained wetlands (20\%) and built-up areas 4\%." (HELCOM 2007a). Urbanization and industrialization started early and forests and wetlands are far from their natural state. The catchment of the Baltic Sea is under heavy anthropogenic influence with many industrial areas and a population of 85 million people. None of the sub-basins of the Baltic Sea is considered to have an acceptable environmental status and the whole sea is contaminated with hazardous substances with a status of mainly moderate (HELCOM 2010b).

The volume of the Baltic Sea is approximately $20,000 \mathrm{~km}^{3}$ (HELCOM 2007a) and the theoretical time for complete exchange of water with the North Sea is approximately 25-35 years (Skowrońska et al. 2009). Baltic Sea consists of nine sub-basins that differ in size, physiographic and biological properties and pollution load. Biodiversity is limited due to these special conditions. Pollutants in the Baltic Sea has been monitored intensively for decades by HELCOM (Helsinki Convention on the Protection of the Marine Environment of the Baltic Sea Area) and its member states. This has revealed the distribution, trends in and ecological importance of pollutants. In relation to HELCOM target levels PCB is top of the listed pollutants followed by $\mathrm{Pb}, \mathrm{Hg}$ and ${ }^{137} \mathrm{Cs}$ (HELCOM 2010a). Eutrophication, hazardous substances in biota and oxygen depletion in bottom waters and sediments are the most important issues in the Baltic Sea environment. In this review the focus is directed towards concentrations and trends in pollutant levels of three metals $(\mathrm{Cd}, \mathrm{Pb}$ and $\mathrm{Hg}$ ) and radionuclides and the factors influencing these trends.

Many factors affect the concentrations of pollutants, including anthropogenic emissions, political decisions and legislation, climate change, eutrophication and fisheries. These factors are interrelated and the outcome difficult to predict. These complex ecological-social systems require holistic approaches like EBM (Ecosystem Based Management) or DPSIR (Drivers, Pressures, State changes, Impacts and Responses) (e.g. Skowrońska et al. 2009, Elmgren et al. 2015). Increasing environmental awareness, technological development and the collapse of communism in Eastern Europe have resulted in the

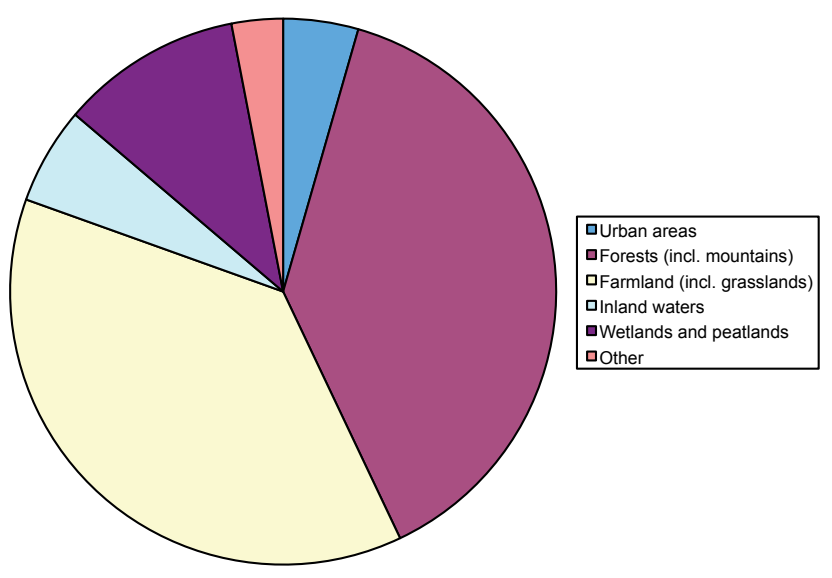

Fig. 1 Land use around the Baltic Sea (data from HELCOM 2002). 
closure of many polluting industries (Vallius 2014). Although emissions of heavy metals and other persistent pollutants have decreased substantially in the catchment area over the last few decades there are still worryingly high concentrations in parts of the Baltic ecosystem.

\section{Loads of Heavy Metals}

External pollution comes via rivers and coastal sources, from the North Sea and the atmosphere. Emissions originate from urban, agricultural and industrial sources. The waterborne emissions of $\mathrm{Cd}, \mathrm{Pb}$ and $\mathrm{Hg}$ from rivers are considerably bigger than the atmospheric deposition (Table 1). The waterborne inputs include runoff from terrestrial areas (diffuse, urban and industrial sources including hotspot areas). The great rivers contribute significantly to the load of $\mathrm{Cd}, \mathrm{Pb}$ and $\mathrm{Hg}$ (Table 2). A list of hotspot areas was established by HELCOM in 1992 and over two thirds of these sites have now been removed from the list. The remaining 45 sites include industrial, agricultural and municipal sources.

Table 1 Annual waterborne emissions and atmospheric deposition (tonnes) of three metals in the Baltic Sea (inputs of $\mathrm{Hg}$ from Polish rivers not included).

\begin{tabular}{|l|c|c|c|}
\hline & Cd & Pb & Hg \\
\hline Waterborne inputs (HELCOM 2011) & 47.7 & 282 & 0.8 \\
\hline Atmospheric deposition (HELCOM 2007b) & 5.7 & 235 & 2.9 \\
\hline Total input & 53.4 & 517 & 3.7 \\
\hline
\end{tabular}

Table 2 The most important inputs ( $t$; average annual inputs for 20052007) of Cd, Pb and Hg via rivers into the Baltic Sea (HELCOM 2010b).

\begin{tabular}{|l|c|c|c|}
\hline & $\mathbf{C d}$ & $\mathbf{P b}$ & $\mathbf{H g}$ \\
\hline Kemijoki & - & - & 0.06 \\
\hline Lule älv & - & 4 & - \\
\hline Vistula & 9 & 27 & - \\
\hline Swedish Bothnian Sea coast & 4 & - & - \\
\hline Kyrönjoki & 0.24 & - & - \\
\hline Dalälven & 0.24 & - & 0.05 \\
\hline Karvianjoki & 0.18 & - & - \\
\hline Götaälven & 0.19 & 9 & - \\
\hline Kokemäenjoki & 1.3 & 10 & - \\
\hline Polish open sea coast & - & - & 0.6 \\
\hline Neva & 29 & 125 & - \\
\hline Narva & - & 8 & 0.14 \\
\hline Slupia & - & - & 0.19 \\
\hline Daugava & - & - & 0.06 \\
\hline Lupawa & - & - & 0.12 \\
\hline Nemunas & -12 & 9 & 0.8 \\
\hline Leba & - & - & 0.29 \\
\hline Pasleka & -14 & - \\
\hline Total & -386 & 2.3 \\
\hline
\end{tabular}

The atmospheric deposition of lead remained rather high even after European Union banned the use of leaded gasoline in vehicles in 2000. According to EMEP (2013) the annual atmospheric deposition of cadmium had increased in 2011 to 7.2 tonnes while that of lead and mercury had decreased to 194 and 2.8 tonnes respectively (Table 3). The greatest emissions came from Poland. The deposition of Cd is approximately $5-10 \mathrm{~g} / \mathrm{km}^{2}$ in the northern parts (Bothnian Bay, Bothnian Sea, Archipelago Sea, Gulf of Finland) and approximately $20 \mathrm{~g} / \mathrm{km}^{2}$ in the southern parts (Gulf of Riga, Baltic Proper, Western Baltic, The Sound, Kattegat). For lead the deposition is approximately $0.5 \mathrm{~kg} \mathrm{~km}^{-2}$ and approximately $0.7 \mathrm{~kg} \mathrm{~km}^{-2}$ in the south. For mercury the figures are approximately $6 \mathrm{~g} \mathrm{~km}^{-2}$ and $10 \mathrm{~g} \mathrm{~km}^{-2}$, respectively (Gusev 2015).

The annual amounts of heavy metals deposited from the atmosphere into the Baltic Sea decreased in the period from 1990 to 2012 by $53 \%$ for cadmium, $23 \%$ for mercury and $79 \%$ for lead (Gusev 2014). The annual anthropogenic emission from HELCOM countries made up approximately $37 \%$ of the cadmium, $20 \%$ of the lead and approximately $14 \%$ of the mercury, respectively, deposited into the Baltic Sea in 2011 (Gusev 2009).

Table 3 Atmospheric deposition ( $\mathrm{t} \mathrm{a}^{-1}$ ) of three metals in 1990, 2000 and 2013 into the Baltic Sea (Gusev 2015).

\begin{tabular}{|l|c|c|c|}
\hline & Cd & Pb & Hg \\
\hline 1990 & 16.0 & 913 & 4.5 \\
\hline 2000 & 12.0 & 429 & 4.0 \\
\hline 2013 & 5.6 & 177 & 3.2 \\
\hline
\end{tabular}

\section{Heavy Metals in Sediments}

Concentrations of heavy metals in sea water are generally very low and old results are not necessarily reliable. Dippner and Pohl (2004) report mean concentrations of total (dissolved and particulate) metals in the Western Baltic Sea of 15.5, 84 and $7 \mathrm{ng} \mathrm{l}^{-1}$ for $\mathrm{Cd}, \mathrm{Pb}$ and $\mathrm{Hg}$, respectively. The concentrations are similar above and below the halocline. The concentrations show a decreasing trend over the period 1990-1995: 62\%, 66\% and 74\% for $\mathrm{Cd}, \mathrm{Pb}$ and $\mathrm{Hg}$, respectively. A small but essential part of the heavy metals in the water is exported into the North Sea (14\%, $4.1 \%$ and $26 \%$ for $\mathrm{Cd}, \mathrm{Pb}$ and $\mathrm{Hg}$, respectively). According to Zalewska et al. (2015) reference values (for a period of little anthropogenic pressure) for $\mathrm{Cd}, \mathrm{Pb}$ and $\mathrm{Hg}$ are $0.3 \mathrm{mg} \mathrm{kg}^{-1}, 30 \mathrm{mg} \mathrm{kg}^{-1}$ and $0.05 \mathrm{mg} \mathrm{kg}^{-1}$, respectively, in the southern parts of Baltic Sea.

In aquatic environments metals and radionuclides are to a great extent bound to inorganic or organic particles and sedimented. There are estimates of surface sediment concentrations and metal accumulation for the northern parts of the Baltic Sea (Table 4). Metals are removed from the water phase mainly by sedimentation and fishing. Sediments act as a sink for heavy metals as new organic 
and inorganic material cover older sediments. The concentrations in sediment cores indicate decreasing loads (Vallius and Leivuori 1999; Leivuori 2000; Vallius 2014). Heavy metals may be strongly but not totally irreversibly bound to sulphides or in other forms under anoxic conditions (e.g. Calmano et al. 1993). The binding to more or less insoluble sulphides is very strong for $\mathrm{Cd}$ and $\mathrm{Pb}$, whereas $\mathrm{Hg}$ is enriched to a lesser extent at anoxic sites. The bioavailability of metals depends on chemical binding and solubility. In shallow water, especially, biological activity and currents may mix the sediments and bring metals back into circulation. As the physical and biological conditions of bottoms vary within a wide range it is difficult to quantify the amounts of metals that are recirculated. The estimated annual sedimentation of $\mathrm{Cd}, \mathrm{Pb}$ and $\mathrm{Hg}$ is 113, 3084 and 6.8 tonnes, respectively, for the entire Baltic Sea in the 1980's (Borg and Jonsson 1996). These figures are much higher than the estimated input in 2004 (Table 1).

Sediment cores from deep water may reveal temporal trends in metal sedimentation but dating and interpretation of the results are not always straightforward. The vertical distribution of metals in sediments varies widely between different areas. In many cases background values can be found in sediments from the 19th century, while anthropogenic influence increases during the 20th century. Over the last few decades sediment concentrations have decreased as a result of decreased emissions. In the Gulf of Riga this development is clear for $\mathrm{Cd}$ and $\mathrm{Hg}$, while surprisingly there is only a small decrease in $\mathrm{Pb}$ (Fig. 2; Leivuori et al. 2000). In the Gulf of Gdansk the highest $\mathrm{Pb}$ concentrations (63-147 $\left.\mu \mathrm{g} \mathrm{g}^{-1}\right)$ were measured in sediments deposited between 1960s and 1970s and the fraction of anthropogenic $\mathrm{Pb}$ was estimated to be 93\% (Zaborska 2014). Also in the Gulf of Finland most trends in heavy metal concentrations (including $\mathrm{Cd}, \mathrm{Pb}$ and $\mathrm{Hg}$ ) are decreasing (Vallius 2012), whereas earlier

Table 4 Average concentrations ( $\mathrm{mg} \mathrm{kg}^{-1}$ d.w.) of $\mathrm{Cd}, \mathrm{Pb}$ and $\mathrm{Hg}$ in surface sediments and total annual accumulation $\left(\mathrm{t} \mathrm{a}^{-1}\right)$ in four sea areas (data from Leivuori et al. 2000). Estimates for the whole Baltic Sea for the 1980s from Borg and Jonsson 1996 (1) and Leivuori et al. 2000 (2; based on accumulation in the four northern sea areas).

\begin{tabular}{|l|l|r|r|r|}
\hline & & \multicolumn{1}{c|}{$\mathbf{C d}$} & \multicolumn{1}{c|}{$\mathbf{P b}$} & $\mathbf{~ H g}$ \\
\hline Gulf of Finland & concentration & 1.06 & 50 & 0.13 \\
\hline & accumulation & 10.70 & 452 & 1.60 \\
\hline Bothnian Bay & concentration & 0.94 & 79 & 0.27 \\
\hline & accumulation & 4.20 & 356 & 1.20 \\
\hline Bothnian Sea & concentration & 0.37 & 42 & 0.09 \\
\hline & accumulation & 1.60 & 185 & 0.40 \\
\hline Gulf of Riga & concentration & 0.73 & 39 & 0.10 \\
\hline & accumulation & 3.30 & 175 & 0.50 \\
\hline Baltic Sea & accumulation (1) & 113 & 3084 & 6.80 \\
\hline & accumulation (2) & 55 & 3244 & 10.30 \\
\hline
\end{tabular}

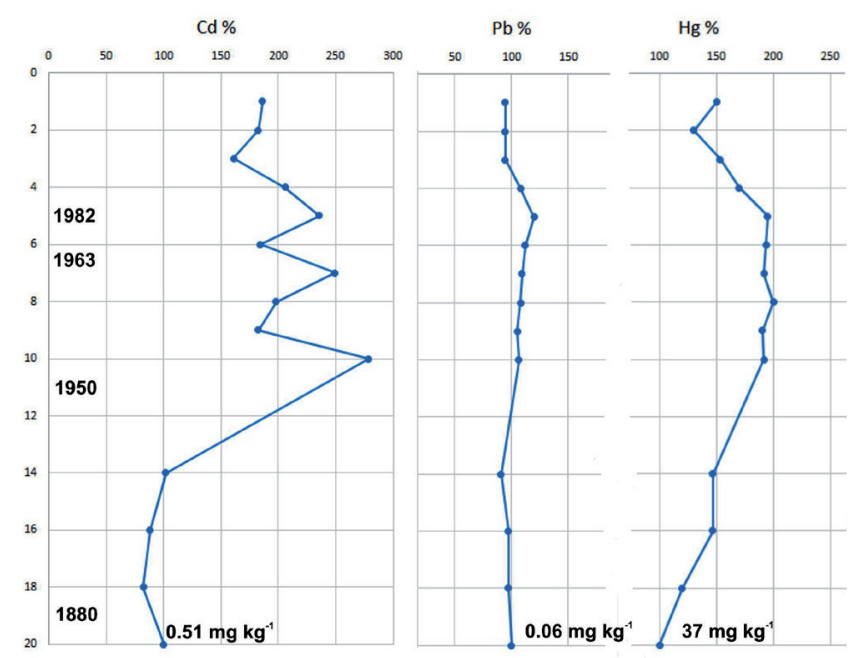

Fig. 2 Vertical sediment profiles for $\mathrm{Cd}, \mathrm{Pb}$ and $\mathrm{Hg}$ in the Gulf of Riga as percentages of background concentrations ( $\mathrm{mg} \mathrm{kg}^{-1} \mathrm{~d}$.w.). Age of dated sediment layers indicated to the left (data from Leivuori et al. 2000).

Vallius and Leivuori (1999) noted increasing Cd concentrations in the Gulf of Finland.

Heavy metals, especially cadmium, may be toxic to benthic organisms. This toxicity may be strongly dependent on temperature, salinity and oxygen concentration. In general, decreasing salinity and increasing temperature increases the toxicity of cadmium and other heavy metals. For lead toxicity stressful salinity enhance the toxic effects, while temperature has no significant effect. Suboptimal salinity and temperature may increase the sensitivity of benthic animals to mercury (McLusky et al. 1986; Strode and Balode 2013).

\section{Heavy Metals in Biota}

In the marine environment heavy metals and radionuclides are partly sedimented and partly taken up by the biota, including fish. The concentrations in fish vary widely but in most cases the trend is decreasing (Polak-Juszczak 2009, 2013; Voigt 1999, 2007).

A great part of the heavy metals and radionuclides in the Baltic Sea is bound to living and dead organisms and biota may significantly affect the fluxes of pollutants. Knowledge of the different food chains and their dynamics is essential for understanding the circulation of pollutants. Concentrations and trends of heavy metals in fish, mussels and sediments have been reported for some decades. During the 1980's and 1990's there was an increase and then a decrease after that. The temporal trends are not always significant and they are different for different samples, areas and pollutants (HELCOM 2010a).

Fish samples, e.g. sprat, herring, cod and flatfish, analyzed from different parts of the Baltic Sea revealed significant downward trends for $\mathrm{Cd}, \mathrm{Hg}$ and $\mathrm{Pb}$ (Polak-Juszczak (2010, 2013; Table 5). When analyzing temporal trends in heavy metals in fish (liver for Cd and 
$\mathrm{Pb}$, muscle for $\mathrm{Hg}$ ) from different parts of the Baltic Sea (Jensen 2012) found both increasing (two areas) and decreasing (one area) trends in the period 1980-2010 for cadmium but only decreasing trends for lead (five areas) and mercury (five areas) in herring. Metal concentrations are usually measured in muscle or liver samples but whole fish concentrations might reflect the environmental status better (Boalt et al. 2014).

A removal of biomass e.g. through fishing may significantly reduce the total amounts of pollutants in the aquatic environment (e.g. Mackenzie et al. 2004; Szefer 2013). However, the rough estimates of the amounts of metals removed from the Baltic Sea through fishing (Table 6) seem to be much smaller compared to the above mentioned (Table 4; Borg and Jonsson 1996) amounts sedimented in the 1980 's.

Table 5 Concentrations (means \pm S.D. wet weight) of $\mathrm{Cd}, \mathrm{Pb}$ and $\mathrm{Hg}$ in the muscle of fish from the Southern Baltic Sea in the period 1994-2003 (Polak-Juszczak 2009, 2010).

\begin{tabular}{|l|c|c|c|c|c|}
\hline Flounder & Year & $\mathbf{n}$ & $\mathbf{C d} \boldsymbol{\mu g} / \mathbf{k g}$ & $\mathbf{P b} \boldsymbol{\mu g} / \mathbf{k g}$ & $\mathbf{H g} \boldsymbol{\mu g} / \mathbf{k g}$ \\
\hline & 1996 & 21 & $2.4 \pm 2.3$ & $22.0 \pm 9.0$ & $66 \pm 26$ \\
\hline & 2003 & 26 & $1.0 \pm 1.0$ & $4.4 \pm 3.6$ & $50 \pm 21$ \\
\hline Herring & 1994 & 40 & $16.0 \pm 6.0$ & $39.0 \pm 25.0$ & $84 \pm 12$ \\
\hline & 2003 & 54 & $6.1 \pm 3.0$ & $8.0 \pm 9.0$ & $22 \pm 13$ \\
\hline Sprat & 1994 & 36 & $29.0 \pm 15.0$ & $44.0 \pm 31.0$ & $68 \pm 25$ \\
\hline & 2003 & 41 & $14.0 \pm 2.4$ & $11.0 \pm 10.0$ & $14 \pm 5.0$ \\
\hline Cod & 1994 & 9 & $4.0 \pm 1.0$ & $17.0 \pm 5.0$ & $118 \pm 11$ \\
\hline & 2003 & 30 & $0.1 \pm 0.4$ & $5.0 \pm 7.0$ & $31 \pm 22$ \\
\hline
\end{tabular}

Table 6 Annual removal of $\mathrm{Cd}, \mathrm{Pb}$ and $\mathrm{Hg}(\mathrm{kg})$ by fishing estimated using catch statistics for 2010 (ICES) and fish muscle concentrations for 2003 (Polak-Juszczak 2009, 2010; concentration for "others" means those for the above mentioned species). The figures are adjusted upwards by $35 \%$ in order to take into account discards and recreational fishing (Zeller et al. 2011).

\begin{tabular}{|l|c|c|c|}
\hline & $\mathbf{C d}$ & $\mathbf{P b}$ & $\mathbf{H g}$ \\
\hline Herring & 0.32 & 1.4 & 16.0 \\
\hline Sprat & 2.90 & 3.8 & 10.0 \\
\hline Cod & 1.1 & 0.86 & 1.1 \\
\hline Flounder & 0.002 & 0.10 & 0.63 \\
\hline Others & 0.13 & 0.17 & 0.72 \\
\hline Total & $\mathbf{4 . 4}$ & $\mathbf{6 . 3}$ & $\mathbf{2 9 . 0}$ \\
\hline
\end{tabular}

\section{Radionuclides in the Baltic Sea}

The most significant sources of anthropogenic radioactivity in the Baltic Sea is fallout from nuclear weapons tests carried out in the 1950s and 1960s and from the Chernobyl accident in 1986 (Table 7). The majority of the radionuclide emissions from Chernobyl were short-lived and ${ }^{137} \mathrm{Cs}$ was the most important long-lived isotope. The estimated amount of ${ }^{137} \mathrm{Cs}$ entering the Baltic Sea from this accident was estimated to be $4.7 \mathrm{PBq}$ (HELCOM 2009). For radionuclides the general trend in the Baltic Sea environment (water, surface sediments and fish) is steadily decreasing (HELCOM 2009; Zalewska and Suplińska 2013).

In the sediments anthropogenic radioactive isotopes are unevenly distributed with the highest concentrations in the Gulf of Riga (max. $385 \mathrm{~Bq}^{137} \mathrm{Cs} \mathrm{kg}^{-1}$ in the uppermost layer) and lower concentrations in the north and west. In the southern Baltic Sea the mean deposition varied from 1900 in the Bornholm Deep to $5500 \mathrm{~Bq} \mathrm{~m}^{-2}$ in the Gulf of Gdansk. In benthic plants ${ }^{137} \mathrm{Cs}$ concentration from 3 to $40 \mathrm{~Bq} \mathrm{~kg}^{-1} \mathrm{~d}$.w. were recorded. In bivalves and crustaceans the ${ }^{137} \mathrm{Cs}$ concentrations varied from 1 to $5 \mathrm{~Bq} \mathrm{~kg}^{-1} \mathrm{~d}$.w. and the ${ }^{90} \mathrm{Sr}$ concentrations varied from 0.6 to $1.2 \mathrm{~Bq} \mathrm{~kg}^{-1} \mathrm{~d}$.w. In herring the ${ }^{137} \mathrm{Cs}$ concentrations have decreased steadily from approximately 15 in 1989 to under 5 in 2010 Bq kg-1 d.w. (Zalewska and Suplińska 2013).

Table 7 Sources of inputs (\%) of two radionuclides into the Baltic Sea (HELCOM 2009).

\begin{tabular}{|l|c|c|}
\hline & ${ }^{137}$ Cs & ${ }^{90}$ Sr \\
\hline Sources beyond the Baltic Sea & 4 & 6 \\
\hline Nuclear weapons testing & 14 & 81 \\
\hline Chernobyl accident & 82 & 13 \\
\hline
\end{tabular}

The greatest part (64-65\%) of ${ }^{90} \mathrm{Sr}$ and ${ }^{137} \mathrm{Cs}$ in sediments is in the Bothnian Sea, while ${ }^{241}$ Am is more evenly distributed between the sea basins. The total sediment loads of ${ }^{90} \mathrm{Sr},{ }^{241} \mathrm{Am}$ and ${ }^{137} \mathrm{Cs}$ is estimated to be $21,8.4$ and $2050 \mathrm{TBq}$ respectively (Hutri et al. 2013). The sediment concentrations of these nuclides is very variable (Table 8). In the Baltic Sea the effective half-life of ${ }^{137} \mathrm{Cs}$ is estimated to be approximately 10 years and that of ${ }^{90} \mathrm{Sr}$ 16 years (Ikäheimonen et al. 2009).

Table 8 Mean concentrations $(\mathrm{Bq} \mathrm{m})$ of ${ }^{90} \mathrm{Sr},{ }^{241} \mathrm{Am}$ and ${ }^{137} \mathrm{Cs}$ in sediments in the Baltic Sea (Hutri et al. 2013).

\begin{tabular}{|l|c|c|c|}
\hline & N & Mean & S.D. \\
\hline${ }^{90} \mathrm{Sr}$ & 22 & 225 & 433 \\
\hline${ }^{241} \mathrm{Am}$ & 19 & 65 & 66 \\
\hline${ }^{137} \mathrm{Cs}$ & 22 & 20,350 & 26,680 \\
\hline
\end{tabular}

\section{Large-scale Environmental Changes and Interacting Multiple Stressors}

Anthropogenic pollution, eutrophication and climate change are large-scale (global or regional) drivers affecting the Baltic Sea environment. A great number of factors affect the future development of metal concentrations 
and these factors are often interrelated and the outcome difficult to predict:

- anthropogenic emissions that are related to technological and economic development,

- changes in atmospheric deposition of pollutants,

- political decisions and legislation in countries around the Baltic sea,

- climate change and changes in temperature, salinity and water currents,

- changes in eutrophication and oxygen status, and related changes in biota and

- changes in fisheries and fish stocks.

The factors governing pollutant levels in the Baltic Sea are to a great extent interrelated (Table 9). Many papers deal with the predicted effects of an ongoing and future global climate change (e.g. Philippart et al. 2011; Störmer 2011; Blenckner et al. 2015). Scenarios for future development of the Baltic Sea environment are complicated and uncertain.

\section{Temperature and Ice Cover}

The mean temperature in the Baltic Sea area has been predicted to increase by approximately $2-5{ }^{\circ} \mathrm{C}$ by the end of this century (HELCOM 2007a; Neumann 2010; Störmer 2011; Meier et al. 2012; Andersson et al. 2015). Increasing temperatures will lead to spatially and temporally decreasing ice cover: up to $50-85 \%$ decrease in ice extent by 2100 (Andersson et al. 2015). Decreasing ice cover affects photosynthesis and other biological processes. Warming could lead to a lengthening of the growing season by as much as 20 to 50 days for northern areas and 30-90 days for southern areas by the late 21 st century (HELCOM 2007a). These changes in temperature will most probably also affect the species composition in the Baltic marine ecosystem with more freshwater species and fewer marine species (e.g. Schiedek et al. 2007). A possible global rise in sea level will also affect the Baltic Sea and e.g. the exchange of water with the North Sea.

Increasing temperature may affect both exposure to heavy metals and other hazardous substances and their toxic effects (Heugens et al. 2001; Cherkasov et al. 2006; Lanning et al. 2006). Species of marine origin and cold water species have limited possibilities to adapt to decreasing salinity and increasing temperature (Schiedek et al. 2007). Higher temperatures may be more favourable for warm water species including bloom-forming toxic cyanobacteria (HELCOM 2007a). Elevated temperatures may enhance bioavailability and toxicity of some hazardous substances (Heugens et al. 2001). Reduced salinity may enhance uptake of heavy metals by aquatic organisms (McLusky et al. 1986). Exposure to heavy metals in combination with elevated temperature may increase the oxygen demand of aquatic organisms (Cherkasov et al. 2006; Lanning et al. 2006).

\section{Input and Concentrations of Heavy Metals and Radionuclides}

The emissions of heavy metals have steadily decreased during the last decades due to technological improvements. This development will probably continue but perhaps more slowly than in the past. Heavy metals will still be strongly bound by anoxic sediments and mostly separated from the marine ecosystem. Although the trends for heavy metals in fish are not unambiguously decreasing it is reasonable to predict lower concentrations in the long run.

Normally the emissions of radionuclides are very low and the amounts are decreasing as a result of decay. Accidents at nuclear facilities may unpredictably cause emissions and deposition of ${ }^{137} \mathrm{Cs}$ or other radionuclides.

\section{Precipitation, Water Inflow, Evaporation, Salinity and Acidification}

Several estimates (e.g. Graham et al. 2008; Blenckner et al. 2015) indicate increasing precipitation and increasing inflow of freshwater from rivers. Precipitation may increase up to $30 \%$ in the north, causing both a decrease in salinity and increase in the input of organic matter. An increased river runoff will increase the inputs of harmful substances including nutrients and heavy metals bound to organic matter (Andersson et al. 2015).

Increase in precipitation in the Baltic Sea area will cause a decrease in salinity, which may affect water stratification and the oxygen concentration in deep water (e.g. Störmer 2011; Carstensen et al. 2014; Blenckner et al. 2015). Warmer water and decreased salinity may have significant consequences for aquatic organisms. The concentrations of $\mathrm{CO}_{2}$ in the atmosphere is continuously increasing, which may lead to increased risk of marine acidification (Meier et al. 2012). Increasing $\mathrm{CO}_{2}$ may also enhance photosynthesis. Salinity greatly affects the bioavailability of substances, e.g. metals, the usual trend being an increase in uptake at lower salinities. For the Baltic Sea it is important to remember that most organisms are living in suboptimal conditions which make them more vulnerable to changes in environmental conditions (Heugens et al. 2001).

Predicted future changes in climate for different parts of the Baltic Sea vary with the largest changes in sea surface water expected in summer in the north (Bothnian Sea and Bothnian Bay) and in spring in the Gulf of Finland (Andersson et al. 2015; Blenckner et al. 2015). However, the predicted decrease in salinity at the surface of the sea will be largest in the southern regions (Danish sea areas).

\section{Eutrophication - 0xygen Depletion}

In future the direct emissions of nutrients will probably decrease due to changes in agricultural practices and 
more effective treatment of waste waters, but the total runoff will increase and have uncertain effects on nutrient runoff, primary production and the oxygen status of the Baltic Sea. In the long run eutrophication and algal blooms will decrease but no rapid enhancement can be expected (e.g. Elmgren et al. 2015). The Baltic Sea is the largest anthropogenically induced hypoxic sea area in the world (Carstensen et al. 2014) and a significant improvement in its oxygen status is unlikely (Störmer 2011; Meier et al. 2012). It is likely there will also be large areas with hypoxic/anoxic bottom waters and sediments in the future but the trend is uncertain.

\section{Fish, Other Biota and Biodiversity}

Decreasing salinity will cause a change towards more brackish and freshwater species (e.g. Niiranen et al. 2013). Fishing affects the amounts of pollutants and nutrients removed from the ecosystem but also through changes in populations of fish and other aquatic organisms (e.g. zooplankton). Older fish usually contain higher concentrations of hazardous substances, which means that fishing policy could also be used to direct the flows of heavy metals (Elmgren et al. 2015). Climate change will most probably affect both the exposure to (bioavailability) and toxic effects (including regulation processes) of harmful substances (Heugens et al. 2001; Schiedek et al. 2007).

Table 9 Interrelated factors and pressures governing pollutant levels in the Baltic Sea.

\begin{tabular}{|l|}
\hline Direct anthropogenic influence: \\
- Emissions to water and air \\
- Atmospheric deposition \\
- Fishing \\
\hline Natural processes: \\
- Riverine inflow, exchange with North Sea \\
- Evaporation \\
- Sedimentation \\
\hline Changes related to climate change: \\
- Temperature, ice cover \\
- Precipitation, water inflow, salinity \\
\hline Changes related to eutrophication: \\
- Emissions and concentrations of nutrients \\
- Eutrophication, photosynthesis, biomass \\
- Anoxia or hypoxia in sediments \\
- Fish and other biota, biodiversity \\
\hline
\end{tabular}

\section{Legal Framework, Political Strategies and Economic Consequences}

In order to reduce pollution and enhance coordinated measures for the protection of the marine environment the Helsinki Commission, HELCOM, was established as a result of a convention that was accepted in 1992 and entered into force in January 2000. The convention lists harmful substances, including heavy metals and radioac- tive substances. HELCOM adopted the Baltic Sea Action Plan (BSAP) in 2007 and this plan was revised in 2013. The plan aims to limit or reduce eutrophication and concentrations of hazardous substances and promote scientific cooperation and monitoring. A good ecological status of the Baltic marine environment should be achieved by 2021 . The action areas include agriculture, industry, urban areas, hazardous substances, wastes and marine littering as well as planning, monitoring and establishment of protection areas. The goals for hazardous substances are:

- Concentrations of hazardous substances close to natural levels.

- All fish are safe to eat.

- Healthy wildlife.

- Radioactivity at the pre-Chernobyl level.

The HELCOM strategy in relation to climate change is to mitigate adverse effects and enhance the resilience of the Baltic marine environment to future changes in climate. This will include measures:

- to mitigate eutrophication by intensifying the reduction of waterborne and airborne nutrient inputs,

- to continue and intensify measures to reduce inputs of heavy metals and persistent or hazardous organic pollutants,

- to reduce emissions from maritime transport and stop vessels from releasing ballast water,

- to enhance the protection of marine and coastal landscapes and habitats and, in particular, the conservation of native Baltic species (HELCOM 2007a).

Heavy metal emissions are also regulated by the Convention on Long-Range Transboundary Air Pollution by heavy metals (CLRTAP-HM). It was adopted in Aarhus (Denmark) in 1998 and entered into force in 2003. It targets, especially, mercury, cadmium and lead. According to the convention participating countries are committed to reduce their emissions of these three metals below their levels in 1990 by using the best available techniques.

TheultimatetargetleveloftheBSAPistoreachnearbackground concentrations of cadmium and mercury in fish. The maximum levels for fish muscle is 50 and $500 \mu \mathrm{g} \mathrm{kg}^{-1}$ cadmium and mercury, respectively (higher levels permitted in pike and eel). Especially for mercury, the background levels in fish are usually clearly lower than the maximum levels (e.g. Voigt 1999, 2007; Polak-Juszczak 2009, 2010). For ${ }^{137} \mathrm{Cs}$ the target is pre-Chernobyl levels, which is $2.5 \mathrm{~Bq} \mathrm{~kg}^{-1}$ (w.w.) for herring muscle and $2.9 \mathrm{~Bq} \mathrm{~kg}^{-1}$ (w.w.) for plaice and flounder muscle. During the period immediately after the establishment of HELCOM and BSAP the inputs of heavy metals into the Baltic Sea were significantly reduced. The legal base for BSAP is two EU directives directly relevant to the Baltic Sea environment: the Water Framework Directive (WFD) and the Marine Strategy Framework (MSFD). The strategical base is an ecosystem-based management (EBM) with humans as integral parts of the managed system (e.g. Blenckner et al. 2015). 
A healthy sea has several benefits for the general public: recreation, fishing, boating etc. Eutrophication and pollution are a considerable nuisance as they result in unhealthy fish and a decrease in recreational value. Different combinations of eutrophication, climate change and fishing policies may affect the stocks of cod, sprat and herring very differently (e.g. Niiranen et al. 2013). These changes may also have considerable economic effects. Climate change is estimated to cause cost the Baltic Sea area: 15 billion euros if the climatic change is moderate and 36 billion euros if it is extreme (Ahlvik and Hyytiäinen 2015).

\section{Concluding Remarks}

Eutrophication and climate change are major problems for the marine environment of the Baltic Sea. The amounts of heavy metals circulating in biota are small but it is still important to monitor their concentrations and effects, even though the emissions have been significantly reduced. Metal concentrations in water, sediments and biota are still too high in many areas. This is true e.g. for cadmium and mercury in sediments (Vallius 2014). The amounts of radionuclides are small and their activity decreasing. Large scale changes, like eutrophication and climate change affect ecosystems in many ways, directly and indirectly, causing biological and abiotic effects. The factors influencing metal concentrations are interacting in a complex manner that is difficult to predict. The HELCOM cooperation has been successful but there are many serious problems that remain to be resolved including many of the predicted effects related to climate change. Measures aiming to enhance the ecological status of the Baltic Sea will certainly give positive results but this will take at least several decades (Noyes et al. 2009; HELCOM 2010b; Sobek et al. 2015). The time scale is very short in a geological sense but long in a political context.

\section{REFERENCES}

Ahlvik L, Hyytiäinen K (2015) Value of adaptation in water protection - Economic impacts of uncertain climate change in the Baltic Sea. Ecol Econ 116: 231-240.

Andersson A, Meier M, Ripszam M, Rowe O, Wikner J, Haglund P, Eilola K, Legrand C, Figueroa D, Paczkowska J, Lindehoff E, Tysklind T, Elmgren R (2015) Projected future climate change and Baltic Sea ecosystem management. Ambio 44: S345-S356.

Blenckner T, Österblom H, Larsson P, Andersson A, Elmgren R (2015) Baltic Sea ecosystem-based management under climate change: Synthesis and future challenges. Ambio 44: S507-S515.

Boalt E, Miller A, Dahlgren H (2014) Distribution of cadmium, mercury, and lead in different body parts of Baltic herring (Clupea harengus) and perch (Perca fluviatilis): Implications for environmental status assessments. Mar Pollut Bull 78: 130-136.

Borg H, Jonsson P (1996) Large-Scale Metal Distribution in Baltic Sea Sediments. Mar Pollut Bull 32: 8-21.
Calmano W, Hon J, Förstner U (1993) Binding and Mobilization of Heavy-Metals in Contaminated Sediments Affected by $\mathrm{pH}$ and Redox Potential. Water Sci Technol 28: 223-235.

Carstensen J, Andersen J, Gustafsson B, Conley D (2014) Deoxygenation of the Baltic Sea during the last century. PNAS 111: 5628-5633.

Cherkasov A, Biswas PK, Ridings DM, Amy H, Ringwood AH, Sokolova IM (2006) Effects of acclimation temperature and cadmium exposure on cellular energy budgets in the marine mollusk Crassostrea virginica: linking cellular and mitochondrial responses. J Exp Biol 209: 1274-1284.

Dippner JW, Pohl C (2004) Trends in heavy metal concentrations in the Western and Central Baltic Sea waters detected by using empirical orthogonal functions analysis. J Mar Syst 46: 69-83.

Elmgren R (2001) Understanding Human Impact on the Baltic Ecosystem: Changing Views in Recent Decades. Ambio 30: 222-231.

Elmgren R, Blenckner T, Andersson A (2015) Baltic Sea management: Successes and failures. Ambio 44: S335-S344.

EMEP (2013) Atmospheric Supply of Nitrogen, Lead, Cadmium, Mercury and Dioxins/Furans to the Baltic Sea in 2013. In: Bartnicki J, Gusev A, Aas W, Valiyaveetil S, Nyíri A (eds) EMEP/ MSC-W TECHNICAL REPORT 2/2013.

Graham LP, Deliang C, Christensen OB, Kjellström E, Krysanova V, Meier HEM, Radziejewski M, Räisänen J, Rockel B, Ruosteenoja K (2008) Projections of future anthropogenic climate change. In: BACC Author Team (eds) Assessment of climate change for the Baltic Sea basin. Springer, Berlin and Heidelberg.

Gusev A (2009) Atmospheric deposition of heavy metals to the Baltic Sea. HELCOM Indicator Fact Sheets 2009. Available at http://www.helcom.fi/environment2/ifs/ifs2009/en_GB /hmdeposition/.

Gusev A (2014) Atmospheric deposition of heavy metals. Atmospheric deposition of heavy metals on the Baltic Sea. Baltic Sea Environment Fact Sheet 2014, Published 22.10.2014.

Gusev A (2015) Atmospheric deposition of heavy metals on the Baltic Sea. HELCOM Baltic Sea Environment Fact Sheets [Published: 27 October 2015, Viewed 27.4.2016], http://www.helcom .fi/baltic-sea-trends/environment-fact-sheets/.

HELCOM (2002) Environment of the Baltic Sea area 1994-1998 (2002) HELCOM, Baltic Sea Environ Proc No. 82B.

HELCOM (2007a) Climate Change in the Baltic Sea Area - HELCOM Thematic Assessment in 2007. Baltic Sea Environ Proc 111.

HELCOM (2007b) Heavy Metal Pollution to the Baltic Sea in 2004. Baltic Sea Environ Proc 108.

HELCOM (2009). Radioactivity in the Baltic Sea, 1999-2006. HELCOM thematic assessment. Baltic Sea Environ Proc No. 117.

HELCOM (2010a) Hazardous substances in the Baltic Sea An integrated thematic assessment of hazardous substances in the Baltic Sea. Baltic Sea Environ Proc No. 120B.

HELCOM (2010b) Ecosystem Health of the Baltic Sea 2003-2007: HELCOM Initial Holistic Assessment. Baltic Sea Environ. Proc. No. 122.

HELCOM (2011) The Fifth Baltic Sea Pollution Load Compilation (PLC-5). Baltic Sea Environ Proc No. 128.

Heugens EHW, Hendriks AJ, Dekker T, vanStraalen N, Admiraal W (2001) A review of the effects of multiple stressors on aquatic organisms and analysis of uncertainty factors for use in risk assessment. Crit Rev Toxicol 31: 247-284.

Hutri K-L, Mattila J, Ikäheimonen T, Vartti V-P (2013) Artificial radionuclides ${ }^{90} \mathrm{Sr}$ and ${ }^{241} \mathrm{Am}$ in the sediments of the Baltic Sea: Total and spatial inventories and some temporal trends. Mar Pollut Bull 70: 210-218. 
Ikäheimonen TK, Outola I, Vartti V, Kotilainen P (2009) Radioactivity in the Baltic Sea: inventories and temporal trends of ${ }^{137} \mathrm{Cs}$ and ${ }^{90} \mathrm{Sr}$ in water and sediments. J Radioanal Nucl Chem 282 : 419-425.

Jensen JN (2012) Contaminants in Herring. Temporal trends in contaminants in Herring in the Baltic Sea in the period 19802010. Baltic Sea Environment Fact Sheet 2012.

Lanning G, Cherkasiv AS, Sokolova IM (2006) Temperature dependent effects of cadmium on mitochondrial and whole-organism bioenergetics in oysters. Mar Environ Res 62: S79-S82.

Leivuori M (2000) Distribution and Accumulation of Metals in Sediments of the Northern Baltic Sea. Finnish Inst Marine Res - Contributions 2.

Leivuori M, Jokòas K, Seisuma Z, Kulikova I, Petersell V, Larsen B, Pedersen B, Floderus S (2000) Distribution of heavy metals in sediments of the Gulf of Riga, Baltic Sea. Boreal Env Res 5: 165-185.

Mackenzie BR, Almesjö L, Hansson S (2004) Fish, fishing, and pollutant reduction in the Baltic Sea. Environ Sci Technol 38: 1970-1976.

McLusky D, Bryant V, Campbell R (1986) The Effects of Temperature and Salinity on the Toxicity of Heavy Metals to Marine and Estuarine Invertebrates. Oceanogr Mar Biol Ann Rev 24: 481-520.

Meier M, Andersson H, Arheimer B, Blenckner T, Chubarenko B, Donnelly C, Eilola K, Gustafsson B, Hansson A, Havenhand J, Höglund A, Kuznetsov I, MacKenzie B, Müller-Karulis B, Neumann T, Niiranen S, Piwowarczyk J, Raudsepp U, Reckermann M, Ruoho-Airola T, Savchuk O, Schenk F, Schimanke S, Väli G, Weslawski J-M, Zorita E (2012) Comparing reconstructed past variations and future projections of the Baltic Sea ecosystem - first results from multi-model ensemble simulations. Environ Res Lett 7: 034005 doi:10.1088/1748-9326/7/3/034005.

Neumann T (2010) Climate-change effects on the Baltic Sea ecosystem: a model study. J Mar Syst 81: 213-224.

Niiranen S, Yletyinen J, Tomczak MT, Blenckner T, Hjerne O, MacKenzie BR, Müller-Karulis B, Neumann MT, Meier M (2013) Combined effects of global climate change and regional ecosystem drivers on an exploited marine food web. Global Change Biol 19: 3327-3342.

Noyes P, McElwee M, Miller H, Clark B, Van Tiem L, Walcott K, Erwin K, Levin E (2009) The toxicology of climate change: Environmental contaminants in a warming world. Environ Internat 35: 971-986.

Philippart CJM, Anadón R, Danovaro R, Dippner JW, Drinkwater KF, Hawkins SJ, Oguz T, O'Sullivan G, Reid PC (2011) Impacts of climate change on European marine ecosystems: Observations, expectations and indicators. J Exper Mar Biol Ecol 400: 52-69.

Polak-Juszczak L (2009) Temporal trends in the bioaccumulation of trace metals in herring, sprat, and cod from the southern Baltic Sea in the 1994-2003 period. Chemosphere 76: 1334-1339.

Polak-Juszczak L (2010) Bioaccumulation and temporal trends of trace elements in flounder from the southern Baltic Sea for the 1996-2003 period. J Toxicol Environ Health A73: 1186-1193.
Polak-Juszczak L (2013) Trace elements in the livers of cod (Gadus morhua L.) from the Baltic Sea: levels and temporal trends. Environ Monit Assess 185: 687-694.

Schiedek D, Sundelin B, Readman J, Macdonald R (2007) Interactions between climate change and contaminants. Mar Pollut Bull 54: 1845-1856.

Skowrónska K, Chrzanowski W, Namiesnik J (2009) Identification of Chemical Pollution Problems and Causes in the Baltic Sea in Relation to Socio-Economic Drivers. Polish J Environ Studies 18: 701-709.

Sobek A, Sundqvist K, Assefa A, Wiberg K (2015) Baltic Sea sediment records: Unlikely near-future declines in PCBs and HCB. Sci Total Environ 518-519: 8-15.

Strode E, Balode M (2013) Toxico-resistance of Baltic amphipod species to heavy metal. Crustaceana 86: 1007-1024.

Störmer O (2011) Climate Change Impacts on Coastal Waters of the Baltic Sea. In: Schernewski G et al. (eds) Global Change and Baltic Coastal Zones, Chapter 4. Coastal Research Library 1, pp: 51-69 DOI 10.1007/978-94-007-0400-8_4.

Szefer P (2013) Safety assessment of seafood with respect to chemical pollutants in European Seas. Oceanol Hydrobiol Studies 42: $110-118$.

Vallius H (2012) Arsenic and heavy metal distribution in the bottom sediments of the Gulf of Finland through the last decades. Baltica 25: 23-32.

Vallius H (2014) Heavy metal concentrations in sediment cores from the northern Baltic Sea: declines over the last two decades. Mar Pollut Bull 79: 359-364.

Vallius H, Leivuori M (1999) The distribution of heavy metals and arsenic in recent sediments of the Gulf of Finland. Boreal Environ Res 4: 19-29.

Vallius H (2014) Heavy metal concentrations in sediment cores from the northern Baltic Sea: Declines over the last two decades. Mar Pollut Bull 79: 359-364.

Voigt H-R (1999) Concentrations of heavy metals in fish from coastal waters around the Baltic Sea. ICES J Mar Sci 56 (Suppl.): $140-141$.

Voigt H-R (2007) Heavy Metal (Hg, Cd, Zn) Concentrations and Condition of Eelpout (Zoarces viviparus L.), around Baltic Sea. Polish J Environ Stud 16: 909-917.

Zaborska A (2014) Anthropogenic lead concentrations and sources in Baltic Sea sediments based on lead isotopic composition. Mar Pollut Bull 85: 99-113.

Zalewska T, Suplińska M (2013) Anthropogenic radionuclides ${ }^{137} \mathrm{Cs}$ and ${ }^{90} \mathrm{Sr}$ in the southern Baltic Sea ecosystem. Oceanol 55: 485-517.

Zalewska T, Woroń J, Danowska B, Suplińska M (2015) Temporal changes in $\mathrm{Hg}, \mathrm{Pb}, \mathrm{Cd}$ and $\mathrm{Zn}$ environmental concentrations in the southern Baltic Sea sediments dated with ${ }^{210} \mathrm{~Pb}$ method. Oceanol 57: 32-43.

Zeller D, Rossing P, Harper S, Persson L, Booth S, Pauly D (2011) The Baltic Sea: Estimates of total fisheries removals 1950-2007. Fish Res 108: 356-363. 